\title{
BDNF blood serum linkage with BDNF gene polymorphism (rs6265) in thyroid pathology patients in the West-Ukrainian population
}

\author{
Iryna I. KAMYshnA ${ }^{1}$, Larysa B. PAVlovych ${ }^{2}$, Larysa P. SydorchuK ${ }^{2}$, Igor V. MALYK ${ }^{3}$, \\ Aleksandr M. KAMYSHNYI ${ }^{1}$

\section{'I. Horbachevsky Ternopil National Medical University, Ukraine; ${ }^{2} H S E E U$ "Bukovinian State Medical University", Chernivtsi, Ukraine; ${ }^{3}$ Yuriy Fedkovych Chernivtsi National University, Ukraine \\ E-mail: Iryna.bilous2017@gmail.com}

Objective. Brain-derived neurotrophic factor (BDNF) is identified as an important growth factor involved in learning and memory. Patients with Hashimoto's thyroiditis can suffer from cognitive dysfunction, whereas BDNF is directly regulated by thyroid hormones. It seems reasonable to propose that changes in BDNF expression underlie some of the persistent neurological impairments associated with hypothyroidism.

Methods. The study involved a total of 153 patients with various forms of thyroid pathology. BDNF levels in the sera of the patients and healthy individuals were quantified using enzymelinked immunosorbent assay with highly sensitive Human BDNF ELISA Kit. Genotyping of the BDNF (rs6265) gene polymorphism using TaqMan probes and TaqMan Genotyping Master Mix (4371355) on CFX96"'Real-Time PCR Detection System. Polymerase chain reaction (PCR) for TaqMan genotyping was carried out according to the kit instructions.

Results. Distribution rs6265 variants in the patients depending on the different types of thyroid pathology showed no significant difference in the relative frequency of BDNF polymorphic variants. Presence of hypothyroidism, regardless of its cause (autoimmune or postoperative), there was a decrease in the serum BDNF levels in all genotypes carriers compared with the control group. The analysis of the correlation between BDNF levels and the levels of thyroid-stimulating hormone (TSH), thyroxine (T4), anti-thyroglobulin (anti-Tg), and anti-thyroid peroxidase (anti-TPO) antibodies showed a significant inverse relationship between BDNF and TSH levels $(\mathrm{p}<0.001)$, a direct correlation between BDNF and T4 levels in the blood $(\mathrm{p}<0.001)$, and a weak direct relationship between anti-Tg and BDNF levels ( $\mathrm{p}=0.0157)$.

Conclusion. The $\mathrm{C}$ allele presence is protective and associates with the lowest chances for reduced serum BDNF levels in thyroid pathology patients in the West-Ukrainian population. However, the T-allele increases the risk of low BDNF levels almost 10 times in observed subjects.

Key words: BDNF, autoimmune thyroiditis, hypothyroidism

Hashimoto's thyroiditis (HT) is a chronic autoimmune disease of the thyroid gland caused by elevated thyroid antibodies and characterized by inflammation of the thyroid (goiter). A growing number of studies have suggested that patients with HT can suffer from cognitive impairment (Djurovic et al. 2018). Therefore, it is important to identify risk factors contributing to the development of the cognitive impairment in HT patients.

Brain-derived neurotrophic factor (BDNF) is identified as an important growth factor involved in learning and memory (Sable et al. 2021). BDNF is directly regulated by thyroid hormones and plays a crucial role in the fetal brain development (Hung et al.

Corresponding author: Iryna I. Kamyshna, MD, PhD, Department of Medical Rehabilitation, I. Horbachevsky Ternopil National Medical University, Majdan Voli 1, Ternopil, Ukraine, 46001; phone+380954313068; e-mail: Iryna.bilous2017@gmail.com. 
2018). BDNF is expressed in various cells, including neurons, and it also can pass the blood-brain barrier (Puhlmann et al. 2021). A previous study has demonstrated the positive relationship between BDNF levels with the function of the CNS and peripheral nervous system (Xiong et al. 2021). Moreover, BDNF expressed in the brain has been implicated in the development of mental disorders and studies suggesting that peripheral BDNF can potentially be used as a marker of these diseases in humans (Peters et al. 2021).

In view of these important roles of BDNF, several studies have examined the relationship between thyroid hormone $(\mathrm{TH})$ and the expression of this neurotrophin in developing brains (Memarpour et al. 2020). It seems reasonable to propose that changes in BDNF expression underlie some of the persistent neurological impairments associated with hypothyroidism. The BDNF protein is encoded by the BDNF gene, which is polymorphic in humans. One of the most investigated single nucleotide polymorphisms (SNP) gene, is the rs6265 polymorphism (Martens et al. 2021). The $\mathrm{G}$ to $A$ substitution at position 196 of the coding sequence results in a substitution of valine for methionine at codon position 66 (Val66Met) in the pro-domain of BDNF (Lim et al. 2020). Pro-BDNF translated with this substitution cannot be normally sorted into the secretory vesicles, resulting in the reduction of BDNF levels (Wei et al. 2012).

In the previous studies, we have demonstrated that autoimmune thyroiditis (AIT) and hypothyroidism can affect transcription of the genes involved in neurogenesis, nerve impulse transmission, and cell cycle regulation (Bilous et al. 2020a,b; Bilous et al. 2021; Kamyshna 2021a,b,c). These changes in gene expression can play a role in the development of neurological complications associated with the thyroid pathology.

In this study, we examined the BDNF blood serum levels linkage with BDNF gene polymorphism (rs6265) in thyroid pathology patients in the WestUkrainian population.

\section{Materials and Methods}

Subjects. The study involved a total of 153 patients with various forms of thyroid pathology. The subjects were divided into three groups: group $1 \quad(n=16)$ included patients with postoperative hypothyroidism (PO); group $2(\mathrm{n}=65)$ included patients with hypothyroidism induced by autoimmune thyroiditis (AIT), and group $3(\mathrm{n}=72)$ included patients with both AIT and elevated serum antibodies anti-thyroglobulin (anti-Tg) and anti-thyroid peroxidase (anti-TPO). Twenty-five healthy individuals were randomly and without matching for age or sex recruited as a control group. The clinical and biochemical characteristics of the subjects are presented in Table 1.

The diagnosis of the hypothyroidism was reached using the 2012 Guidelines from the American Association of Clinical Endocrinologists. The diagnosis of AIT took into account relevant clinical features, results of thyroid sonogram (reduced echogenicity), and detected circulating antibodies to thyroid antigens, anti-TPO, and anti-TG (Garber et al. 2012).

Table 1

Clinical and biochemical characteristics of the subjects

\begin{tabular}{|c|c|c|c|c|c|}
\hline & $\begin{array}{l}\text { Reference } \\
\text { values }\end{array}$ & $\begin{array}{l}\text { Control group } \\
(n=25)\end{array}$ & $\begin{array}{l}\text { Patients with } \\
\text { PO }(n=16)\end{array}$ & $\begin{array}{l}\text { Patients with AIT-induced } \\
\text { hypothyroidism } \\
\text { (AIT with hypothyroidism) } \\
(\mathrm{n}=65)\end{array}$ & $\begin{array}{l}\text { Patients with AIT and } \\
\text { elevated anti-Tg and anti- } \\
\text { TPO antibodies } \\
(\text { AIT, } n=72)\end{array}$ \\
\hline Age (years) & & $46.08 \pm 14.58$ & $47.30 \pm 12.27$ & $46.72 \pm 15.49$ & $45.02 \pm 13.65$ \\
\hline $\mathrm{fT} 4(\mathrm{pmol} / \mathrm{L})$ & $7.0-13.5$ & $8.91 \pm 0.97$ & $3.44 \pm 0.31$ & $4.13 \pm 0.52$ & $8.51 \pm 0.82$ \\
\hline $\mathrm{TSH}(\mathrm{mIU} / \mathrm{mL})$ & $0.3-4.0$ & $2.67 \pm 0.52$ & $8.61 \pm 0.84$ & $7.09 \pm 0.50$ & $2.38 \pm 0.62$ \\
\hline anti-TPO (IU/mL) & $0-30$ & $34.04 \pm 3.70$ & $36.13 \pm 2.78$ & $380.62 \pm 73.42$ & $330.36 \pm 50.23$ \\
\hline anti-TG (IU/mL) & $0-65$ & $15.32 \pm 1.97$ & $15.50 \pm 1.90$ & $32.97 \pm 4.27$ & $36.38 \pm 7.70$ \\
\hline $\begin{array}{l}\text { Current dose of } \\
\text { L-thyroxine }(\mu \mathrm{g} / \text { day })\end{array}$ & & None & $110.95 \pm 5.25$ & $88.46 \pm 1.55$ & None \\
\hline $\mathrm{BDNF}(\mathrm{pg} / \mathrm{ml})$ & & $1037.80 \pm 361.83$ & $\begin{array}{c}310.19 \pm 112.84 \\
(p<0.001)\end{array}$ & $\begin{array}{c}329.34 \pm 312.57 \\
(p<0.001)\end{array}$ & $\begin{array}{c}1031.34 \pm 385.00 \\
(p=0.95)\end{array}$ \\
\hline
\end{tabular}

Abbreviations: AIT - autoimmune thyroiditis; anti-Tg - anti-thyroglobulin; BDNF - brain-derived neurotrophic factor; fT4 free thyroxine; PO - postoperative hypothyroidism; TPO - anti-thyroid peroxidase; TSH - thyroid-stimulating hormone. Data are presented as a mean \pm standard deviation. Student's t-test was used for statistical analysis. The value p represents statistical significance between the control group and the study groups. 
Study exclusion criteria were as follows: less than 18 years of age, malignancy, inflammation due to rheumatic diseases or acute/chronic infection, diabetes mellitus, vascular, chronic hepatic or renal diseases, and pregnancy. Individuals taking any drugs that could interfere with thyroid function were also excluded from the study.

The study fully adhered to principles outlined in the 1975 Helsinki Declaration of Human Rights (amended in 2008). The participants enrolled voluntarily after completing and signing a written informed consent. The study protocol was approved by the respective ethics committees of I. Horbachevsky Ternopil National Medical University and Chernivtsi Regional Endocrinology Center.

Hormone levels. Blood samples from the patients and control individuals were collected in the morning (8:00 to 10:00 a.m.), following an overnight fast. For each individual enrolled in the study, levels of thyroxine (fT4, normal range 6.0-13.0 pmol/L for males and 7.0-13.5 pmol/L for females), thyroidstimulating hormone (TSH, normal range 0.3-4.0 $\mathrm{mIU} / \mathrm{mL}$ ), anti-thyroid peroxidase (anti-TPO, normal range $0-30 \mathrm{IU} / \mathrm{mL}$ ) and anti-thyroglobulin (anti-TG, normal range 0-65 $\mathrm{IU} / \mathrm{mL}$ ) were determined using STAT FAX303/Plus analyzer (Awareness Technology Inc, USA).

Enzyme-linked immunosorbent assay (ELISA). BDNF levels in the sera of the patients and healthy individuals were quantified using enzyme-linked immunosorbent assay with highly sensitive Human BDNF (Brain Derived Neurotrophic Factor) ELISA Kit (Elabscience ${ }^{\infty}$, United States, Catalog No: E-ELH0010) on E.I.A. Reader Sirio S (Seac, Italy).

Genotyping of the BDNF (rs6265) gene polymorphism. DNA isolation. Venous blood was collected in a sterile Vacutainer and stabilized with K2EDTA. Total DNA was isolated from peripheral blood using PREP-RAPID-GENETICS DNA Extraction Kit (DNA-TECHNOLOGY, Russian Federation), according to the manufacturer's instructions.

DNA amplification and genotyping. The samples were genotyped using TaqMan probes and TaqMan Genotyping Master Mix (4371355) on CFX96 ${ }^{\text {tm }}$ RealTime PCR Detection System (Bio-Rad Laboratories, Inc., USA). Polymerase chain reaction (PCR) for TaqMan genotyping was carried out according to the kit instructions (Applied Biosystems, USA). TaqMan Genotyping Master Mix contains DNA polymerase AmpliTaq Gold ${ }^{\circ}$, dNTPs, reference dye $\mathrm{ROX}^{\mathrm{m}}$, and buffer ingredients. TaqMan probes are target-specific oligonucleotides with reporter dyes attached to the 5' end of each probe: $\left(\mathrm{VIC}^{\oplus}\right.$ dye on the $5^{\prime}$ end of the Allele
1 probe and 6FAM ${ }^{\mathrm{m}}$ dye on the 5 ' end of the Allele 2 probe), and a non-fluorescent quencher (NFQ) the 3 ' end of the probe. Genomic DNA was amplified in a $10 \mu$ reaction mix containing genomic DNA, forward and reverse primers, fluorescent probes, and TaqMan Genotyping Master Mix. Genotyping of the samples performed on the CFX-Manager ${ }^{\text {tw }}$ software using the method of allele discrimination based on the magnitude of relative fluorescence units (RFU, Figure 1).

Statistical analysis. To determine the difference between groups, we used the Student's t-test, ANOVA, Pearson's $\chi^{2}$ test, odds ratio test, relative odds ratio test, and equality 0 correlation test. We calculated the odds ratio and $95 \%$ confidence interval (CI) using binary logistic regression. A p-value $<0.05$ was considered a statistically significant difference between the two groups.

\section{Results}

In the groups of patients with postoperative hypothyroidism (PO) and primary hypothyroidism, as a result of AIT, there was a probable decrease in fT4 levels in 2.6 and 2.16 times, respectively, compared with the control group. As it is shown in Table 1, TSH levels were significantly higher in these groups by 3.2 and 2.65 times, respectively. At the same time, in patients with primary hypothyroidism as a result of AIT, the level of anti-TPO and anti-TG were 11.2 and 2.16 times higher in this group than in the control group. Patients in Group 3 had a 9.7-fold increase in anti-TPO and 2.4-fold anti-TG levels compared to the control group.

We analyzed allele and genotype frequency BDNF rs6265 in patients with thyroid pathology and the control group. The relative frequency of these polymorphic gene variants did not differ between both groups (Table 2).

The odds ratio (OR) test indicates that the distribution of genotypes CC, CT, and TT did not differ between the study and control groups. The CC genotype of the BDNF gene (rs6265) was predominant (67.9\%) in the surveyed population: among patients $67.97 \%$ vs. $68 \%$ in the control group. The heterozygous CT genotype was the second most common: $25.49 \%$ vs. $24 \%$. The TT genotype was the least common: $6.54 \%$ in the study group vs. $8 \%$ in the control group $(\mathrm{p}>0.05)$.

The $\mathrm{C}$ allele of the BDNF gene was 4.18 times more frequent compared to the $\mathrm{T}$ allele in the thyroid patients $(\mathrm{p}<0.001)$ and 4 times in the control group $(\mathrm{p}<0.001)$. The frequency of both alleles did not differ between the groups: among the thyroid pathology 
Table 2

Distribution of BDNF rs6265 polymorphism in the surveyed population

\begin{tabular}{|c|c|c|c|c|}
\hline $\begin{array}{l}\text { BDNF rs6265 n=178 } \\
(\%)\end{array}$ & $\begin{array}{c}\text { Study group } \\
\mathrm{n}=153 \\
(86.96 \%) \\
\end{array}$ & $\begin{array}{c}\text { Control group } \\
\mathrm{n}=\mathbf{2 5} \\
(\mathbf{1 4 . 0 4} \%) \\
\end{array}$ & $\begin{array}{c}\text { OR } \\
{[95 \% \mathrm{CI}]}\end{array}$ & $\chi^{2}(\mathbf{p}$-value $)$ \\
\hline CC genotype & $\begin{array}{c}104 \\
(67.97 \%)\end{array}$ & $\begin{array}{c}17 \\
(68 \%)\end{array}$ & $\begin{array}{c}0.99 \\
{[0.35 ; 2.65]}\end{array}$ & $\begin{array}{l}\chi^{2}<1.0 \\
p>0.05\end{array}$ \\
\hline CT genotype & $\begin{array}{c}39 \\
(25.49 \%)\end{array}$ & $\begin{array}{c}6 \\
(24 \%)\end{array}$ & $\begin{array}{c}1.08 \\
{[0.38 ; 3.56]}\end{array}$ & $\begin{array}{l}\chi^{2}<1.0 \\
p>0.05\end{array}$ \\
\hline TT genotype & $\begin{array}{c}10 \\
(6.54 \%)\end{array}$ & $\begin{array}{c}2 \\
(8 \%)\end{array}$ & $\begin{array}{c}0.8 \\
{[0.16 ; 8]}\end{array}$ & $\begin{array}{l}\chi^{2}<1.0 \\
p>0.05\end{array}$ \\
\hline $\begin{array}{l}\chi^{2} \\
p \text {-value }\end{array}$ & $\begin{array}{c}\chi^{2}=22.077 \\
p<0.001\end{array}$ & $\begin{array}{l}\chi^{2}=16.33 \\
p<0.001\end{array}$ & & \\
\hline C allele & $\begin{array}{c}247 \\
(80.72 \%)\end{array}$ & $\begin{array}{c}40 \\
(80 \%)\end{array}$ & $\begin{array}{c}1.0464 \\
{[0.44 ; 2.23]}\end{array}$ & $\begin{array}{l}\chi^{2}<1.0 \\
p>0.05\end{array}$ \\
\hline T allele & $\begin{array}{c}59 \\
(19.28 \%) \\
\end{array}$ & $\begin{array}{c}10 \\
(20 \%)\end{array}$ & & \\
\hline
\end{tabular}

Abbreviations: BDNF - brain-derived neurotrophic factor; OR - odds ratio; $\mathrm{n}$ - total number

Table 3

Distribution of BDNF rs6265 genotypes in the study group depending on the type of thyroid pathology and control group

\begin{tabular}{|c|c|c|c|c|c|c|c|c|}
\hline $\begin{array}{l}\text { rs6265 } \\
\text { genotype }\end{array}$ & $\begin{array}{c}\text { Control } \\
\text { group } \\
\mathrm{n}=25 \\
(\mathbf{1 4 . 0 4 \% )}\end{array}$ & $\begin{array}{c}\text { Study Group } \\
\mathrm{n}=153 \\
(85.96 \%)\end{array}$ & $\begin{array}{c}\text { Group 1 } \\
\text { PO } \\
n=16 \\
(10.46 \%)\end{array}$ & $\begin{array}{c}\text { Group 2 } \\
\text { AIT with } \\
\text { hypothyroidism } \\
\mathrm{n}=65 \\
(42.48 \%)\end{array}$ & $\begin{array}{c}\text { Group } 3 \\
\text { AIT } \\
n=72 \\
(47.06 \%)\end{array}$ & $\begin{array}{c}\chi^{2} \\
\text { p-value }\end{array}$ & $\begin{array}{c}\text { Total } \\
\mathrm{n}=178 \\
(\%)\end{array}$ & $\begin{array}{c}\text { OR } \\
{[95 \% \mathrm{CI}]}\end{array}$ \\
\hline $\mathrm{CC}$ & $\begin{array}{c}17 \\
(68 \%)\end{array}$ & $\begin{array}{c}104 \\
(67.97 \%)\end{array}$ & $\begin{array}{c}8 \\
(50 \%)\end{array}$ & $\begin{array}{c}46 \\
(70.77 \%)\end{array}$ & $\begin{array}{c}50 \\
(69.44 \%)\end{array}$ & $\begin{array}{l}\chi^{2}<1.0 \\
p>0.05\end{array}$ & $\begin{array}{c}121 \\
(67.97 \%)\end{array}$ & $\begin{array}{c}0.82 \\
{[0.28 ; 2.62]}\end{array}$ \\
\hline CT & $\begin{array}{c}6 \\
(24 \%)\end{array}$ & $\begin{array}{c}39 \\
(25.49 \%)\end{array}$ & $\begin{array}{c}6 \\
(37.5 \%)\end{array}$ & $\begin{array}{c}16 \\
(24.61 \%)\end{array}$ & $\begin{array}{c}17 \\
(23.61 \%)\end{array}$ & $\begin{array}{l}\chi^{2}<1.0 \\
p>0.05\end{array}$ & $\begin{array}{c}45 \\
(25.28 \%)\end{array}$ & $\begin{array}{c}0.53 \\
{[0.11 ; 2.58]}\end{array}$ \\
\hline TT & $\begin{array}{c}2 \\
(8 \%)\end{array}$ & $\begin{array}{c}10 \\
(6.54 \%)\end{array}$ & $\begin{array}{c}2 \\
(12.5 \%)\end{array}$ & $\begin{array}{c}3 \\
(4.62 \%)\end{array}$ & $\begin{array}{c}5 \\
(6.94 \%)\end{array}$ & $\begin{array}{l}\chi^{2}<1.0 \\
p>0.05\end{array}$ & $\begin{array}{c}12 \\
(6.74 \%)\end{array}$ & $\begin{array}{c}0.62 \\
{[0.04 ; 9.4]}\end{array}$ \\
\hline$\chi^{2}$ & $\chi^{2}=16.64$ & $\chi^{2}=120.92$ & $\chi^{2}=3.63$ & $\chi^{2}=57.8$ & $\chi^{2}=57$ & & $\chi^{2}=140$ & \\
\hline$p$-value & $\mathrm{p}<0.001$ & $\mathrm{p}<0.001$ & $\mathrm{p}=0.053$ & $\mathrm{p}<0.001$ & $\mathrm{p}<0.001$ & & $\mathrm{p}<0.001$ & \\
\hline
\end{tabular}

Abbreviations: AIT - autoimmune thyroiditis; BDNF - brain-derived neurotrophic factor; PO - postoperative hypothyroidism; OR odds ratio; $\mathrm{n}$ - total number.

patients $80.72 \%$ carried $\mathrm{C}$ allele vs. $80 \%$ in the control group ( $\mathrm{p}>0.05)$; the respective frequencies for $\mathrm{T}$ allele were $19.28 \%$ vs. $20 \%$ ( $>0.05$ ).

Distribution of rs6265 variants in the patients depending on the different types of thyroid pathology (Table 3) showed no significant difference in the relative frequency of BDNF polymorphic variants among the patients of PO, AIT with hypothyroidism, and AIT groups. In all groups, wild alleles were predominant compared to the mutant ones.

In subsequent experiments, we determined BDNF levels in blood serum (Table 1). Our results show a significant decrease in serum BDNF in patients with postoperative hypothyroidism and in patients with AIT-induced hypothyroidism (3.34 and 5.15 times, respectively) compared to the control group. At the same time, in the patients with AIT without hypo- thyroidism, the level of BDNF was not significantly different from the control group (Table 1).

The BDNF levels in the groups of patients with $\mathrm{PO}$ and AIT with hypothyroidism were significantly lower regardless of genotypes compared to the control group (Table 4). While the BDNF levels were low in both PO and AIT with hypothyroidism groups, there was no significant difference between these groups. In other words, serum BDNF levels were reduced in the patients with hypothyroidism, regardless of its cause (autoimmune or postoperative) and genotypes, compared to the control group.

A study of BDNF levels depending on the rs6265 polymorphism genotype (Table 4) showed the lowest levels in TT genotype carried in all groups of patients compared to the CC genotype carriers. For instance, in the control group, TT genotype carriers had signif- 
Table 4

BDNF levels in patients with different thyroid pathology depending on the rs6265 genotype

\begin{tabular}{|c|c|c|c|c|c|c|}
\hline \multirow{2}{*}{ BDNF genotype } & \multicolumn{6}{|c|}{$\operatorname{rs6265}(\mathrm{M} \pm \mathrm{m})$} \\
\hline & $\mathrm{CC}$ & CT & TT & p5-value & p6-value & p7-value \\
\hline $\begin{array}{l}\text { Control group } \\
\mathrm{n}=25\end{array}$ & $\begin{array}{c}1189.2 \pm 343.788 \\
(17)\end{array}$ & $\begin{array}{c}859.6 \pm 220.1 \\
(6)\end{array}$ & $\begin{array}{c}574.79 \pm 12.1 \\
(2)\end{array}$ & 0.03649 & $<0.001$ & 0.044 \\
\hline $\begin{array}{l}\text { Study group } \\
\mathrm{n}=153\end{array}$ & $\begin{array}{c}692.12 \pm 478.26 \\
(104)\end{array}$ & $\begin{array}{c}461.91 \pm 373.39 \\
(39)\end{array}$ & $\begin{array}{c}347.96 \pm 210.2 \\
(10)\end{array}$ & 0.0675 & 0.0056 & 0.299 \\
\hline p1-value & $<0.001$ & 0.0105 & 0.0119 & & & \\
\hline $\begin{array}{l}\text { PO } \\
n=16\end{array}$ & $\begin{array}{c}386.5 \pm 98.24 \\
(8)\end{array}$ & $\begin{array}{c}241.85 \pm 21.72 \\
(6)\end{array}$ & $\begin{array}{l}179.8 \pm 4.17 \\
(2)\end{array}$ & 0.00733 & 0.0014 & 0.0084 \\
\hline p1-value & $<0.001$ & 0.0031 & 0.0064 & & & \\
\hline p2-value & 0.131 & 0.92 & 0.3146 & & & \\
\hline $\begin{array}{l}\text { AIT } \\
\text { with hypothyroidism } \\
\mathrm{n}=65\end{array}$ & $\begin{array}{c}555.64 \pm 372.75 \\
(46)\end{array}$ & $\begin{array}{c}244.69 \pm 84.89 \\
(16)\end{array}$ & $\begin{array}{c}171.63 \pm 10.35 \\
\text { (3) }\end{array}$ & 0.0087 & 0.002 & 0.01797 \\
\hline pl-value & $<0.001$ & 0.0025 & $<0.001$ & & & \\
\hline p3-value & $<0.001$ & $<0.001$ & 0.00143 & & & \\
\hline $\begin{array}{l}\text { AIT } \\
\mathrm{n}=72\end{array}$ & $\begin{array}{c}1367.19 \pm 294.6 \\
(50)\end{array}$ & $\begin{array}{c}1006.86 \pm 209.9 \\
(17)\end{array}$ & $\begin{array}{c}564.29 \pm 73.35 \\
(5)\end{array}$ & 0.03727 & $<0.001$ & 0.0024 \\
\hline p1-value & 0.2766 & 0.2903 & 0.797 & & & \\
\hline p4-value & 0.00024 & 0.0003 & 0.00177 & & & \\
\hline
\end{tabular}

Abbreviations: AIT - autoimmune thyroiditis; BDNF - brain-derived neurotrophic factor; PO - postoperative hypothyroidism. Notes: p1- Student's t between the control group and study groups; p2- Student's t between PO and AIT with hypothyroidism groups; p3 - Student's t between AIT and AIT with hypothyroidism groups; p4 - Student's t between PO and AIT groups; p5 - Student's t between CC and CT genotypes; p6 - Student's t between CC and TT genotypes; 7 - Student's t between CT and TT genotypes; $n$ total number.

icantly lower serum BDNF levels compared to the CC genotype. Likewise, in all groups of patients with TT genotype, the level of BDNF was significantly lower (PO: 2.15 times; AIT with hypothyroidism: 3.24 times; and AIT: 2.42 times) compared to the patients with CC genotype. Thus, the results indicate the TT genotype carriers have reduced BDNF levels, which can be further exacerbated by the thyroid gland pathology.

Comparative analysis of the BDNF levels of patients with AIT with hypothyroidism and AIT without hypothyroidism showed that BDNF levels in the sera were significantly lower in the patients with AIT with hypothyroidism in carriers of all genotypes. For example, the level of BDNF in carriers of the CC genotype among patients with AIT with hypothyroidism was reduced 2.46 times compared to the CC genotype carriers with AIT. Additionally, among the CT and TT genotypes carriers, these BDNF levels were significantly reduced, 4.11 and 3.29 times, respectively. Thus, it is probable that the levels of thyroid hormones have a greater effect on BDNF than the levels of anti-Tg and anti-TPO antibodies.

In patients with AIT, BDNF levels did not differ significantly from the control group, but a closer look into the correlation between BDNF levels and rs6265 genotypes showed that individuals with TT genotypes had significantly lower BDNF levels compared to those with CT and CC genotypes.

As shown in Table 5, the $\mathrm{C}$ allele carrier is protective and makes the chances of reduced levels of BDNF in the serum of patients with thyroid pathology significantly lower in the examined population $(\mathrm{OR}=0.1 ; 95 \%$ SI OR: 0.002; 09159; $\mathrm{p}=0.021)$. At the same time, the carrier of the T-allele increases the risk of low levels of BDNF in thyroid pathology by almost 10 times $(\mathrm{OR}=9.98 ; \mathrm{p}<0.05)$.

The analysis of correlation between BDNF levels and the levels of TSH, T4, anti-Tg, and anti-TPO antibodies showed a significant inverse relationship between BDNF and TSH levels $(\mathrm{p}<0.001)$, a direct correlation between BDNF and T4 levels in the blood $(\mathrm{p}<0.001)$ and a weak direct relationship between anti-Tg and BDNF levels $(\mathrm{p}=0.0157)$. In addition, we found a direct significant correlation between the levels of anti-TPO and anti-Tg $(\mathrm{p}<0.001)$ and a reverse correlation between the levels of TSH and T4 $(\mathrm{p}<0.001)$ (Figure 2). 


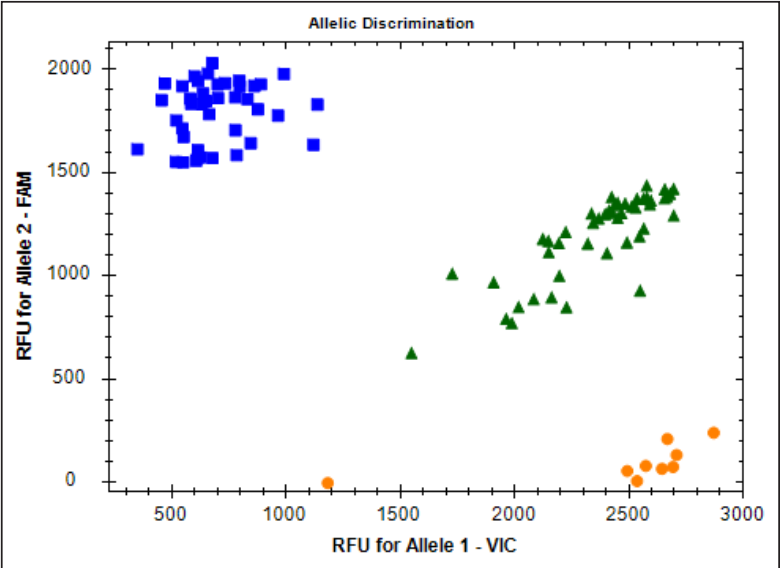

Figure 1. Allelic discrimination (AD) plots the results of the allelic discrimination data as a plot of Allele 1 (VIC ${ }^{\mathrm{m}}$ dye) versus Allele 2 (FAM ${ }^{\mathrm{st}}$ dye). Allelic discrimination analysis is based on the magnitude of relative fluorescence units (RFU). The $\mathrm{AD}$ plot represents each sample well as an individual point on the plot.

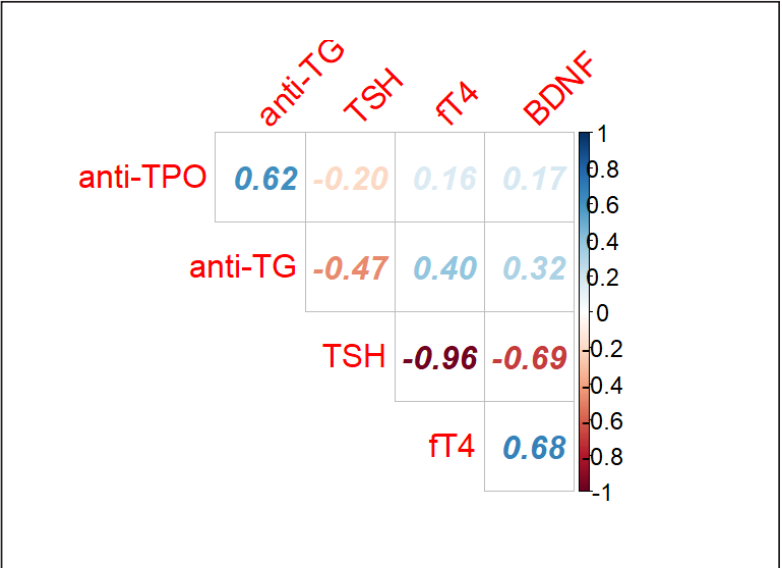

Figure 2. Pearson correlation between the variables brainderived neurotrophic factor (BDNF), anti-thyroid peroxidase (anti-TPO), anti-thyroglobulin (anti-Tg), thyroid-stimulating hormone (TSH) and free thyroxine (fT4) in the study group.

Table 5

Polymorphic variants of the BDNF gene rs6265 as risk factors for reduced serum BDNF levels

\begin{tabular}{llccccc}
\hline BDNF genotype & & RelR & OR & 95\%CI RR & 95\%CI OR & p-value \\
\hline $\begin{array}{l}\text { BDNF level } \\
<500\end{array}$ & CC & 0.208 & 0.1 & $(0.03 ; 1.33)$ & $(0.002 ; 09159)$ & 0.021 \\
& CT & 1.53 & 5.08 & $(1.038 ; 2.25)$ & $(0.55 ; 251)$ & 0.223 \\
& TT & 1.21 & - & $(1.038 ; 1.4)$ & - & 0.076 \\
BDNF level & CT+TT & 2.187 & 9.98 & $(1.35 ; 3.55)$ & $(1.09 ; 493)$ & 0.021 \\
$500-1000$ & CC & 0.225 & 0.131 & $(0.033 ; 1.54)$ & $(0.002 ; 1.78)$ & 0.13 \\
& CT & 1.125 & 1.92 & $(0.77 ; 1.74)$ & $(0.08 ; 134)$ & 1 \\
& TT & 1.5 & & $(0.945 ; 2.38)$ & & 0.023 \\
& CT+TT & 1.968 & 7.63 & $(0.906 ; 4.27)$ & $(0.56 ; 459)$ & 0.13 \\
\hline
\end{tabular}

Abbreviations: BDNF - brain-derived neurotrophic factor; CI - 95\% confidence interval; OR - odds ratio; RelR - relative risk; 95\% CI $\mathrm{RR}$ - confidence interval of risk.

The results of ANOVA between serum BDNF levels and BDNF rs6265 polymorphism (Figure 3A-D) showed a significant correlation between BDNF levels and BDNF rs6265 polymorphism in the $\mathrm{PO}(\mathrm{F}=7.875$, $\mathrm{p}=0.00883)$ and $\mathrm{AIT}(\mathrm{F}=15.06, \mathrm{p}<0.001)$ group.

These results also showed that BDNF levels vary in all groups. Thus, the level of BDNF is different for subsamples of TT, CC, and CT, which is consistent with the results presented in Table 4 .

\section{Discussion}

One of the main directions of biomedical research today is the discovery of the role of genetic factors in the development of widespread multifactorial diseases. An important method used to detect hered- itary predisposition to certain diseases is the analysis of transcriptome (Degen et al. 2020; Putilin et al. 2020) and single nucleotide polymorphism (Dzhuryak et al. 2020; Lyubomirskaya et al. 2020a, b).

In this study, we investigated the correlation of BDNF polymorphism at the rs6265 locus and BDNF serum levels of the patients with various thyroid gland pathologies in the Bukovynian region of Ukraine.

Brain-derived neurotrophic factor (BDNF) is a protein of the neurotrophic family of growth factors. It produces a major impact on the processes of memory formation as well as brain development, such as neurogenesis, synaptogenesis, and neuronal differentiation (Sonoyama et al. 2020). Previous studies have shown that thyroid hormones play an important role in the BDNF expression (Shabani et 

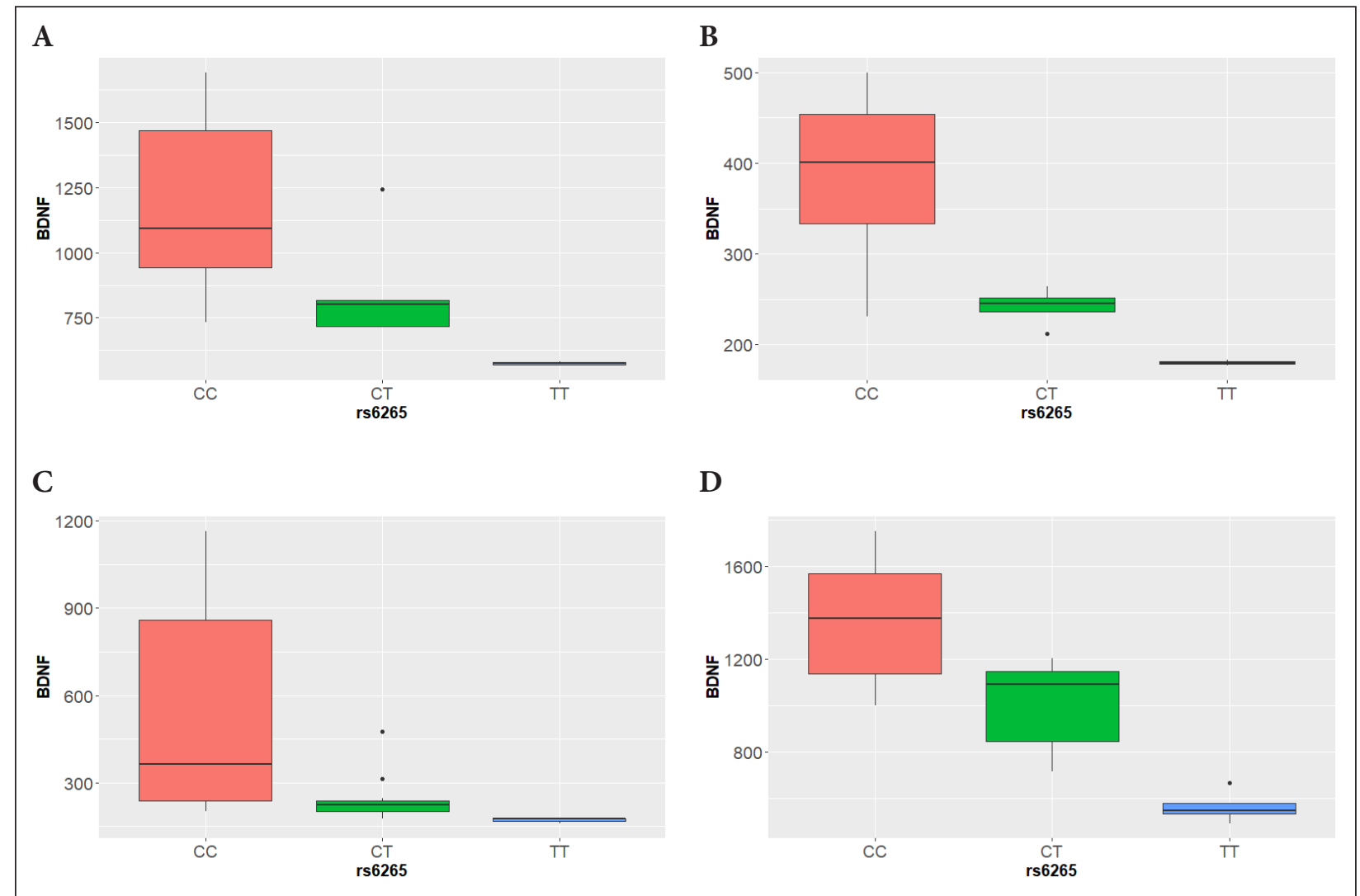

Figure 3. The results of ANOVA between serum brain-derived neurotrophic factor (BDNF) levels (y-axis) and BDNF rs6265 polymorphism (x-axis). (A) Boxplot for BDNF in Control group with rs6265 as group variable; (B) Boxplot for BDNF in patients with postoperative hypothyroidism (PO) with rs6265 as group variable; (C) Boxplot for BDNF in patients with hypothyroidism induced by autoimmune thyroiditis (AIT) with rs6265 as group variable; (D) Boxplot for BDNF in patients with both AIT and elevated serum antibodies anti-thyroglobulin (anti-Tg) and anti-thyroid peroxidase (anti-TPO) with rs6265 as group variable).

al. 2018). BDNF expression, directly regulated by thyroid hormones, plays an essential role especially during the critical period of the fetal brain development (Sanchez-Huerta et al. 2016). Insufficiency of thyroid hormones during development results in the reduced BDNF levels, diminished cognitive functions, and delayed neural development in both humans and experimental animals (Shafiee et al. 2016). For instance, maternal hypothyroidism resulted in a reduced BDNF expression in the developing brain of rat embryos (Liu et al. 2010).

In this study, we found a significant decrease in BDNF levels in the patients with postoperative hypothyroidism and AIT-induced hypothyroidism compared to the control group. At the same time, a comparative analysis of BDNF levels between $\mathrm{PO}$ and AIT with hypothyroidism groups found no significant differences between them. The levels of BDNF in the group of patients with AIT without hypothyroidism did not significantly differ from the control group. This indicates that in the presence of hypothyroidism, regardless of its cause (autoimmune or postoperative), there is a decrease in the serum BDNF levels in the carriers of all genotypes compared with the control group.

Previous studies on the rat model have shown that maternal thyroid dysfunction affects BDNF expression. This, in turn, results in neurological defects, which can be detected in adult animals (Devlin et al. 2021). In humans, clinical studies in patients with major depressive disorder demonstrated that TSH has an inverse association with serum BDNF levels and causes its comparatively minor increase throughout antidepressant therapy (Baek et al. 2014).

Because of the important role of BDNF in the brain, a number of genetic studies have been focused on the effects of BDNF polymorphisms on brain function and behavior in healthy individuals as well as in pathological conditions, particularly neuropsychiatric disorders (Fu et al. 2020). 
Rs6265, a common SNP of BDNF in humans results in an amino acid change from valine to methionine at codon 66 (Val66Met), which is in the pro-domain of BDNF. The Val66Met polymorphism has been shown to interfere with BDNF trafficking and decrease its secretion (Egan et al. 2003). Several studies have found associations between the Val66Met polymorphism and reduced volumes of hippocampal and prefrontal gray matter resulting in abnormal hippocampus activity, impaired cognitive functioning, diminished memory, and executive functions (Notaras and van den Buuse 2019).

In this study, after analyzing the frequency of alleles and genotypes of BDNF rs6265 in patients with thyroid pathology in the Bukovynian region of Ukraine, we found that in this population a wild SS genotype of the rs6265 was predominant (67.9\%). The heterozygous CT genotype was the second most common and the TT genotype the least common (25.49\% and $24 \%$, respectively). The C allele of the rs6265 was predominant in this population compared to the $\mathrm{T}$ allele: 4.18 times more frequent in the patient groups $(\mathrm{p}<0.001)$ and 4 times in the control group $(\mathrm{p}<0.001)$. Similar to many genetic variants, the distribution of $\mathrm{C}$ and $\mathrm{T}$ alleles varies in different ethnic groups. While the $\mathrm{T}$ allele frequency is less than $1 \%$ in African populations, it increases to $17 \%$ in European populations, reaching up to $60 \%$ in Asian populations (Mandelman and Grigorenko 2012). The population frequency of the $\mathrm{T}$ allele found in this study corresponds to the average for European populations: https://cutt.ly/1vnYL4i.

Analysis of BDNF serum levels in the patients with different forms of AIT (with and without hypothyroidism) showed that it was significantly lower in the patients with AIT with hypothyroidism regardless of the rs6265 genotype. Thus, among the patients with AIT with hypothyroidism and CC genotype, BDNF levels were reduced 2.46 times compared to the patients with AIT and the same genotype. Comparison of the same groups of patients with CT and TT genotypes showed a significant reduction of BDNF levels (4.11 and 3.29 times, respectively) in the patients with AIT with hypothyroidism. This suggests that the thyroid hormone levels have a greater effect on BDNF levels than the levels of anti-Tg and anti-TPO antibodies.

The assessment of serum BDNF depending on the rs6265 genotype showed that these levels were lower in TT genotype carriers in all study groups compared to the carriers of CC genotype. Therefore, we can conclude that individuals with TT genotype have reduced levels of BDNF, and these levels can be further exacerbated in the cases of thyroid gland pathology.

Previous studies have supported our findings, individuals homozygous or heterozygous for the Met alleles had lower plasma BDNF than homozygous Val/Val carriers. This can be explained by abnormal intracellular trafficking of the BDNF precursor, which reduces the production of mature BDNF in cells associated with the $\mathrm{T}$ allele (Chen et al. 2004; Egan et al. 2003).

In patients with AIT, BDNF levels did not differ significantly from the control group, however, analysis of the dependence of BDNF levels on rs6265 genotypes showed that the carriers TT genotype had significantly lower BDNF compared to the carriers of CT and CC genotypes. Thus, the T allele in our study is associated with a reduced level of serum BDNF, which is further exacerbated by the elevated titer of anti-Tg and anti-TPO antibodies.

The $\mathrm{C}$ to $\mathrm{T}$ substitution in BDNF results in the change from valine to a methionine amino acid residue codon 66 , located within the BDNF prodomain. This affects a sortilin-binding site resulting in disrupted intracellular trafficking. Without prober binding to sortilin, BDNF proteins affected are not directed to the secretory vesicles, which reduces their activity-dependent secretion (Notaras et al. 2015).

Studies reported that the rs6265 T allele is linked to lower concentrations of blood serum BDNF in healthy German subjects (Gallinat et al. 2010). Mice homozygous for the T allele exhibited reduced basal BDNF levels in the hippocampus. These levels could not be normalized by the administration of antidepressant fluoxetine (Bath et al. 2012). In contrast, another study suggested that The Met allele of the BDNF Val66Met polymorphism is associated with increased BDNF serum concentrations (Lang et al. 2009).

In this study, we found that serum BDNF was the lowest in the PO and AIT with hypothyroidism groups. Also, the rs6265 $\mathrm{T}$ allele is associated with low serum BDNF levels. We suggest that against the background of thyroid pathology, genetic predisposition plays a more substantial role in reducing BDNF. On the other hand, the Val/Val genotype can contribute to the protection of neurons in the cases of thyroid insufficiency and thyroid pathology. Our study is consistent with the evidence that the BDNF is involved in early response to neuronal damage (Lindvall et al. 1994).

In our study, the $\mathrm{C}$ allele is protective and makes the chances of reduced levels of BDNF in the serum 
of patients with thyroid pathology significantly lower in the examined population. On the other hand, the carrier of the T-allele increases the risk of low levels of BDNF in thyroid pathology by almost 10 times.
Taking into account that the effect of thyroid hormones on the brain is incontrovertible and their lack leads to various neurological complications, early diagnosis of damage to the nervous system in thyroid disorders is crucial to prevent and treat neurological complications.

\section{References}

Baek JH, Kang ES, Fava M, Mischoulon D, Nierenberg AA, Lee D, Heo JY, Jeon HJ. Thyroid stimulating hormone and serum, plasma, and platelet brain-derived neurotrophic factor during a 3-month follow-up in patients with major depressive disorder. J Affect Disord 169, 112-117, 2014.

Bath KG, Jing DQ, Dincheva I, Neeb CC, Pattwell SS, Chao MV, Lee FS, Ninan I. BDNF Val66Met impairs fluoxetineinduced enhancement of adult hippocampus plasticity. Neuropsychopharmacology 37, 1297-1304, 2012.

Bilous I, Pavlovych L, Krynytska I, Marushchak M, Kamyshnyi A. Apoptosis and cell cycle pathway-focused genes expression analysis in patients with different forms of thyroid pathology. Open Access Maced J Med Sci 8(B), 784-792, 2020a.

Bilous II, Korda MM, Krynytska IY, Kamyshnyi AM. Nerve impulse transmission pathway-focused genes expression analysis in patients with primary hypothyroidism and autoimmune thyroiditis. Endocr Regul 54, 109-118, 2020 b.

Bilous I, Pavlovych L, Kamyshnyi A. Primary hypothyroidism and autoimmune thyroiditis alter the transcriptional activity of genes regulating neurogenesis in the blood of patients. Endocr Regul 55, 101-111, 2021.

Chen ZY, Patel PD, Sant G, Meng CX, Teng KK, Hempstead BL, Lee FS. Variant brain-derived neurotrophic factor (BDNF) (Met66) alters the intracellular trafficking and activity-dependent secretion of wild-type BDNF in neurosecretory cells and cortical neurons. J Neurosci. 24, 4401-4411, 2004.

Degen AS, Krynytska IY, Kamyshnyi AM. Changes in the transcriptional activity of the entero-insular axis genes in streptozotocin-induced diabetes and after the administration of TNF- $\alpha$ non-selective blockers. Endocr Regul 54, 160-171, 2020.

Devlin P, Cao X, Stanfill AG. Genotype-expression interactions for BDNF across human brain regions. BMC Genomics 22, 207, 2021.

Djurovic M, Pereira AM, Smit JWA, Vasovic O, Damjanovic S, Jemuovic Z, Pavlovic D, Miljic D, Pekic S, Stojanovic M, Asanin M, Krljanac G, Petakov M. Cognitive functioning and quality of life in patients with Hashimoto thyroiditis on long-term levothyroxine replacement. Endocrine 62, 136-143, 2018.

Dzhuryak V, Sydorchuk L, Sydorchuk A, Kamyshnyi O, Kshanovska A, Levytska S, Knut R, Sheremet M, Ivashchuk S, Petrynych O, Kazantseva T, Nikyfor L, Melnychuk L, Sokolenko A, Yarynych Y, Semianiv M, Repchuk Y, Voroniuk K, Sydorchuk R, Sokolenko L, Iftoda O, Kushnir O. The cytochrome 11B2 aldosterone synthase gene CYP11B2 (RS1799998) polymorphism associates with chronic kidney disease in hypertensive patients. Biointerface Research in Applied Chemistry 10, 5406-5411, 2020.

Egan MF, Kojima M, Callicott JH, Goldberg TE, Kolachana BS, Bertolino A, Zaitsev E, Gold B, Goldman D, Dean M, Lu B, Weinberger DR. The BDNF val66met polymorphism affects activity-dependent secretion of BDNF and human memory and hippocampal function. Cell 112, 257-269, 2003.

Fu X, Wang J, Du J, Sun J, Baranova A, Zhang F. BDNF gene's role in schizophrenia: from risk allele to methylation implications. Front Psychiatry 11, 564277, 2020.

Gallinat J, Schubert F, Bruhl R, Hellweg R, Klar AA, Kehrer C, Wirth C, Sander T, Lang UE. Met carriers of BDNF Val66Met genotype show increased $\mathrm{N}$-acetylaspartate concentration in the anterior cingulate cortex. Neuroimage 49, 767-771, 2010.

Garber JR, Cobin RH, Gharib H, Hennessey JV, Klein I, Mechanick JI, Pessah-Pollack R, Singer PA, Woeber KA; American Association of Clinical Endocrinologists and American Thyroid Association Taskforce on Hypothyroidism in Adults. Clinical practice guidelines for hypothyroidism in adults: cosponsored by the American Association of Clinical Endocrinologists and the American Thyroid Association. Endocr Pract 18, 988-1028, 2012.

Hung PL, Hsu MH, Yu HR, Wu KLH, Wang FS. Thyroxin protects white matter from hypoxic-ischemic insult in the immature Sprague-Dawley rat brain by regulating periventricular white matter and cortex BDNF and CREB pathways. Int J Mol Sci 19, 2573, 2018. 
Kamyshna I, Kamyshnyi A. Transcriptional activity of neurotrophins genes and their receptors in the peripheral blood in patients with thyroid diseases in Bukovinian population of Ukraine. Open Access Maced J Med Sci 9(A), 208-216, 2021a.

Kamyshna II, Pavlovych LB, Maslyanko VA, Kamyshnyi AM. Analysis of the transcriptional activity of genes of neuropeptides and their receptors in the blood of patients with thyroid pathology. J Med Life 14, 243-249, 2021 b.

Kamyshna I., Pavlovych L, Malyk I., Kamyshnyi A. 25-OH Vitamin D blood serum linkage with VDR gene polymorphism (rs2228570) in thyroid pathology patients in the West-Ukrainian population. J Med Life 14 (4), 549-556, 2021c.

Lang UE, Hellweg R, Sander T, Gallinat J. The Met allele of the BDNF Val66Met polymorphism is associated with increased BDNF serum concentrations. Mol Psychiatry 14, 120-122, 2009.

Lim YY, Laws SM, Perin S, Pietrzak RH, Fowler C, Masters CL, Maruff P; AIBL Research Group. BDNF VAL66MET polymorphism and memory decline across the spectrum of Alzheimer's disease. Genes Brain Behav 20, e12724, 2020.

Lindvall O, Kokaia Z, Bengzon J, Elmer E, Kokaia M. Neurotrophins and brain insults. Trends Neurosci 17, 490-496, 1994.

Liu D, Teng W, Shan Z, Yu X, Gao Y, Wang S, Fan C, Wang H, Zhang H. The effect of maternal subclinical hypothyroidism during pregnancy on brain development in rat offspring. Thyroid 20, 909-915, 2010.

Lyubomirskaya ES, Kamyshnyi AM, Krut YY, Smiianov VA, Fedoniuk LY, Romanyuk LB, Kravets NY, Mochulska OM. SNPs and transcriptional activity of genes of innate and adaptive immunity at the maternal-fetal interface in woman with preterm labour, associated with preterm premature rupture of membranes. Wiad Lek 73, 25-30, 2020a.

Lyubomirskaya K, Krut Y, Sergeyeva L, Khmil S, Lototska O, Petrenko N, Kamyshnyi A. Preterm premature rupture of membranes: prediction of risks in women of Zaporizhzhia region of Ukraine. Pol Merkur Lekarski 48, 399-405, 2020b.

Mandelman SD, Grigorenko EL. BDNF Val66Met and cognition: all, none, or some? A meta-analysis of the genetic association. Genes Brain Behav 11, 127-136, 2012.

Martens L, Herrmann L, Colic L, Li M, Richter A, Behnisch G, Stork O, Seidenbecher C, Schott BH, Walter M. Met carriers of the BDNF Val66Met polymorphism show reduced Glx/NAA in the pregenual ACC in two independent cohorts. Sci Rep 11, 6742, 2021.

Memarpour S, Beheshti F, Baghcheghi Y, Vafaei AA, Hosseini M, Rashidy-Pour A. Neuronal nitric oxide inhibitor 7-nitroindazole improved brain-derived neurotrophic factor and attenuated brain tissues oxidative damage and learning and memory impairments of hypothyroid juvenile rats. Neurochem Res 45, 2775-2785, 2020.

Notaras M, Hill R, van den Buuse M. The BDNF gene Val66Met polymorphism as a modifier of psychiatric disorder susceptibility: progress and controversy. Mol Psychiatry 20, 916-930, 2015.

Notaras M, van den Buuse M. Brain-derived neurotrophic factor (BDNF): novel insights into regulation and genetic variation. Neuroscientist 25, 434-454, 2019.

Peters RB, Xavier J, Mondin TC, Cardoso TA, Ferreira FB, Teixeira L, Graeff K, Quevedo LA, Jansen K, Souza LD, Oses JP, Pinheiro RT, da Silva RA, Ghisleni G. BDNF Val66Met polymorphism and resilience in major depressive disorder: the impact of cognitive psychotherapy. Braz J Psychiatry 43, 22-28, 2021.

Puhlmann LMC, Linz R, Valk SL, Vrticka P, Vos de Wael R, Bernasconi A, Bernasconi N, Caldairou B, Papassotiriou I, Chrousos GP, Bernhardt BC, Singer T, Engert V. Association between hippocampal structure and serum brain-derived neurotrophic factor (BDNF) in healthy adults: A registered report. Neuroimage 236, 118011, 2021.

Putilin DA, Evchenko SY, Fedoniuk LY, Tokarskyy OS, Kamyshny OM, Migenko LM, Andreychyn SM, Hanberher II, Bezruk TO. The influence of metformin to the transcriptional activity of the mTOR and FOX3 genes in parapancreatic adipose tissue of streptozotocin-induced diabetic rats. J Med Life 13, 50-55, 2020.

Sable HJ, MacDonnchadh JJ, Lee HW, Butawan M, Simpson RN, Krueger KM, Bloomer RJ. Working memory and hippocampal expression of BDNF, ARC, and P-STAT3 in rats: effects of diet and exercise. Nutr Neurosci $1-14,2021$.

Sanchez-Huerta K, Garcia-Martinez Y, Vergara P, Segovia J, Pacheco-Rosado J. Thyroid hormones are essential to preserve non-proliferative cells of adult neurogenesis of the dentate gyrus. Mol Cell Neurosci 76, 1-10, 2016.

Shabani S, Farbood Y, Mard SA, Sarkaki A, Ahangarpour A, Khorsandi L. The regulation of pituitary-thyroid abnormalities by peripheral administration of levothyroxine increased brain-derived neurotrophic factor and reelin protein expression in an animal model of Alzheimer's disease. Can J Physiol Pharmacol 96, 275-280, 2018. 
Shafiee SM, Vafaei AA, Rashidy-Pour A. Effects of maternal hypothyroidism during pregnancy on learning, memory and hippocampal BDNF in rat pups: Beneficial effects of exercise. Neuroscience 329, 151-161, 2016.

Sonoyama T, Stadler LKJ, Zhu M, Keogh JM, Henning E, Hisama F, Kirwan P, Jura M, Blaszczyk BK, DeWitt DC, Brouwers B, Hyvonen M, Barroso I, Merkle FT, Appleyard SM, Wayman GA, Farooqi IS. Human BDNF/ TrkB variants impair hippocampal synaptogenesis and associate with neurobehavioural abnormalities. Sci Rep 10, 9028, 2020.

Wei SM, Eisenberg DP, Kohn PD, Kippenhan JS, Kolachana BS, Weinberger DR, Berman KF. Brain-derived neurotrophic factor $\mathrm{Val}^{66} \mathrm{Met}$ polymorphism affects resting regional cerebral blood flow and functional connectivity differentially in women versus men. J Neurosci 32, 7074-7081, 2012.

Xiong LL, Chen J, Du RL, Liu J, Chen YJ, Hawwas MA, Zhou XF, Wang TH, Yang SJ, Bai X. Brain-derived neurotrophic factor and its related enzymes and receptors play important roles after hypoxic-ischemic brain damage. Neural Regen Res 16, 1453-1459, 2021. 